\title{
Carlo Fantappiè, Ecclesiologia e Canonistica Venezia: Marcianum Press, 2015, 439 pp.
}

The title of the discussed Carlo Fantappiè's publication suggests that the content it includes concentrates around the issues of reciprocity of the two scientific disciplines which are ecclesiology and the science of canon law. The title of the book is very widely defined. It may concern both the methodological issues and the practical normative solutions. What should not escape the attention of an interested reader is the additional issue, namely, the question of the very law in the Church. The connection between ecclesiology and the study of canon law is not so much the consequence of the existence of law in the Church but the law of the Church as her structural element. Every way of practicing ecclesiology, from a preferential point of view, does not remain indifferent to the fact of law in the Church. Ecclesiology yields an answer to the question about law in the Church. I believe, however, that an issue presented in such a way is not a point of interest of canonists, for whom the subject of research, especially within the theology of canon law, should be the fact of law within the vista of redemption, that is, the role which law has in the redemptive act that is realized in the Church and because of the Church. The title of the paper triggers interest in a great many scientific areas.

Carlo Fantappiè divided the content of the book into two parts. The first one is entitled Historical Acquisitions (Acquisizioni storiche). The second one was entitled Border Problems (Problematiche di confine). However, both parts constitute a set of Fantappiè's hitherto publishedpapers (seven) and one new, not published before. Fantappiè's decision to place all of his publications in one volume does not present a juxtaposition of the subsequent studies, but requires a proper key that would make it possible to read it as one piece. Obviously, as the author writes (p. 65), it also required an intervention into thecontent of the publication with a view to adapting and unifying the text, as well as giving 
it a logical and chronological unity. In this way the studies can be viewed as a whole, which proves the fruit of the methodological correctness of the undertaken issue presented in the Introduction to the consecutive parts of the study.

In the reader's eyes, though, the Introduction to the paper fulfills an additional function since from the historical perspective it presents problems connected with a mutual coexistence of two somehow related theological disciplines (i.e., ecclesiology and the study of canon law) and also what undoubtedly is the most interesting thing for the contemporary researchers of the issue, namely, the adroitness at placing the problems that appear on the border of ecclesiology and law in relevant context. The above problems, presented by the Author in particular chapters, do not disclose scientific contemplation but, instead, they uncover practical issues triggered by changes happening in the Church as a result of specific situations.

Reading Fantappiè's book I have an impression that he is familiar with methodological correctness, proper approximation of ecclesiology and the study of canon law enabling the defininition of means of solving the appearing issues, making it possible to continue the discussion, taking up proper normative solutions. Such an approach can be characteristic of every researcher from the outside of the Church community and derive not always concise and real conclusions. The Author of the book directs our attention towards issues resulting from the inside of the Church community, from self-awareness of the Church in the way in which she currently reveals herself. He does not, however, leave questions without answers, suggesting that the renewal of connections between ecclesiology and the study of canon law, which according to him constitute the problems that came to light after the Second Vatical Council, requires proper recognition of new problems with the mutual relation between ecclesiological and canon law knowledge. It will make it possible to avoid unilateral and deficient solutions of Church issues, suggesting that, on the one hand, theology is not far-detached from the real problems requiring finding a solution, and, on the other, canon law is not a tool of achieving the intended goals, incomprehensible without referring them to the essence and goal of the Church.

A proper cooperation of ecclesiology and the study of canon law does not require mere openness of one discipline to the other. The Author turns our attention to traditions and historical references of both scientific disciplines, as well as the necessity of a context reference to various ideas, which appeared in the Church and which influence the process of shaping Church's official doctrine. In order for the relations of ecclesiology and the study of canon law to have a theoretical value and practical reference they cannot focus on the ecclesiological proposal for practical references. The proper relation between ecclesiology and canon law, which is a conveyor translating ecclesiology into the language of canon law requires reaching out for motives, which not only shaped the official doctrine of the Church, but also to the real reasons that influence 
the appearance of new currents of thought within ecclesiology. Since what is connected with these theological concepts creating new and different situations from the accepted ones inside the Church are canon law doctrines referring to the constitution of the Church and problems, which are currently present within both disciplines. The fruitful cooperation of ecclesiology and the study of canon law requires a mutual method of analyzing own claims from a broad historical perspective conditioning their existence, and not only in the light of solutions stemming from the presented wordings.

Carlo Fantappiè does not carry out his speculations as part of theoretical analyses. Each and every detailed issue undertaken by the Author constitutes a valuable reference point for the understanding of the existing situations, which trigger particular questions. The Authormakes it possible to take a closer look on the motives of the situations, indicating towards the possible effects of the cooperation of ecclesiology and study of canon law. Carlo Fantappiè's book of essays constitutes a good basis for a deeper insight into the Church reality and conclusions derived from it, including these of normative character. It allows us to notice the perspective, which does not restrict the needs of the moment.

Tomasz Gatkowski

University of Cardinal Stefan Wyszyński, Warsaw, Poland

(D) https://orcid.org/0000-0001-9166-9516 